\title{
DISCOURSE MARKERS AND MODAL EXPRESSIONS IN SPEAKERS WITH AND WITHOUT ASPERGER SYNDROME: A PRAGMATIC-PERCEPTIVE APPROACH
}

\author{
FRANCISCO J. RODRÍGUEZ MUÑOZ \\ University of Almería \\ frodriguez@ual.es
}

\begin{abstract}
From a theoretical point of view, this paper offers a new framework for the analysis of discourse markers: a pragmatic-perceptive model that emphasizes the point of the communication process in which such particles become more relevant. Furthermore, this approach tries to give an account of the modal expressions (attenuators and intensifiers) that speakers use in oral speech. The quotients of absolute and relative frequency with regard to the use of textual, interactive and enunciative markers - focused on the message, the addressee and the addresser respectively - are compared in two samples of 20 subjects with typical development and other 20 with Asperger syndrome. The general results of this research suggest that these latter speakers display a suitable command of textual markers, whereas they overexploit the enunciative ones in conversation.
\end{abstract}

Keywords: Asperger syndrome, discourse markers, modal expressions, perceptive pragmatics.

\section{Introduction}

Asperger syndrome (AS) is part of the continuum of autistic spectrum disorders, a broad notion that includes individuals with non-functional social behaviour and - specially in AS - with pragmatic communication impairments (Rodríguez-Muñoz 2013). Although the description of AS has been influenced by research on autism, we cannot ignore the particular nature of this disorder. The most important features of AS refer to the literal understanding of language (jokes, humour, double meanings, etc.), but little attention has been paid to other pragmatic features that have been considered intact or undisturbed. That has been the case of discourse markers (DM) and modal expressions (ME).

This study aims to examine the semantic values and pragmatic functions that a set of DM carries out in 40 oral interactions. Twenty of them belong to typical development subjects (TD), whilst the rest belong to AS subjects. The analysis focuses on comparing the absolute and relative frequency of use that these particles have in the oral speech of both groups. The second category that we take into account refers to modality, and we apply the same type of quantitative analysis for the ME used by TD and AS speakers.

$\mathrm{DM}$ and ME, limited to attenuators and intensifiers in our study, may involve the addresser, the addressee or both (Schiffrin 1987). According to the organization of 
pragmatic dimensions suggested by Gallardo (2005, 2006, 2007, 2009), we will propose a synthetic classification for DM depending on their perceptual enhancement. Thus, we distinguish between enunciative, textual and interactive markers when they enhance the addresser, the message or the addressee respectively. From this point of view, a pragmatic orientation predominates over others in communication exchanges (Gallardo and Marín 2005).

As Rodríguez-Muñoz (2009a) has pointed out, the conversations of people diagnosed with AS preserve intact a textual property as basic as cohesion. Therefore, we assume that, in general, there will be no significant statistical differences between the relative frequencies of use for both categories (DM and ME).

\subsection{Discourse markers and modal expressions}

DM are a wide and heterogeneous category whose semantics helps to the interpretation of communicative processes in oral interactions. Contemporary linguistic research has shown a growing interest in these discursive elements. This fact has contributed to a better definition and systematization of them.

The study of DM has arisen from very different perspectives. Nonetheless, all of these can be integrated within a common framework. As Mancera and Placencia (2011) have pointed out, evidence of the multiple approaches that authors have adopted during the last decades is based on the multiple denominations that these linguistic units have received (connectives, pragmatic connectors, discourse operators, discourse particles or markers).

Halliday and Hasan (1976), without explicitly referring to them as DM, understand that these units are functional categories of language that play a basic role in the cohesive textual level, establishing different relationships among utterances. Schiffrin (1987) denominates DM this kind of linguistic unit (conjunctions, interjections, adverbs and lexicalized phrases) that link and depend on other utterances. Fraser's proposal (1990), as a novelty, emphasizes the distinction between the propositional content (semantics) and the pragmatic meaning of utterances where DM appear.

According to the definition provided by Portolés (1998: 25-26), one of the most mentioned in the field of pragmatic studies in Spanish, DM are invariant linguistic units that do not have a syntactic function and that possess a shared purpose in discourse: to guide inferences in communication according to their morphosyntactic, semantic and pragmatic properties.

We cannot ignore, in the case of Spanish DM, key studies that have been developed by authors like Fuentes (1987, 1995, 1996, 2007, 2009), Cortés (1991), MartínZorraquino and Portolés (1999), Briz, Pons and Portolés (2008), Cortés and Camacho (2010) or Loureda and Acín (2010).

Before explaining the classification of DM that we accomplish in the current research, we will discuss the main conceptual models that have been considered:

(a) Syntactic-semantic model: this model gathers all the theoretical attempts in order to formalize the connective categories that are mainly conceived for the purpose of establishing functional associations between the sentences of a text. These connectors are used to express different logic and semantic relationships: 
Addition: 'and' (y), 'moreover' (además).

Option: 'or' $(o)$.

Contrast: 'but' (pero), 'however' (sin embargo), 'although' (aunque) (see Bañón 2003 for details).

Consequence: 'therefore' (por tanto), 'so that' (asi que).

Cause: 'because' (porque), 'since' (ya que).

Explanation: 'that is' (o sea, es decir).

Time: 'when' (cuando), 'afterwards' (después).

Purpose: 'for', 'in order to' (para).

Condition: 'if' (si).

(b) Discursive model: for the classification of DM in Spanish, we follow MartínZorraquino and Portolés (1999), who include different types according to their communicative functions:

Structuring information: commenters ('well' [pues]), organizers ('on the one hand/on the other hand' [por una partelpor otra parte]), and digressors ('by the way' [por cierto]).

Connectors: addition ('moreover', 'furthermore' [además]), consequence ('then' [asi pues]), and contra-argumentation ('instead of' [en lugar de]).

Reformulation markers: of explanation ('that is' [esto es]), of rectification ('rather' [más bien]), of distance ('in any case' [en cualquier caso]), and of recapitulation ('in conclusion' [en conclusión]).

Argumentative operators: intensifiers ('in fact', 'actually' [de hecho]) and specifiers ('in particular' [en particular]).

Conversation markers: of epistemic modality ('for sure' [con seguridad]), of deontic modality ('all right' [de acuerdo]), focusers of otherness ('man', 'look', 'listen' [hombre, mira, escucha]), and metadiscursives ('uh' [eh]).

(c) Pragmatic-perceptive model: despite efforts to integrate DM into a coherent taxonomy being more than significant in the former models, it should be noted that all these particles depend specially on pragmatic constraints imposed by the context. Thus, under the title of pragmatic-perceptive model, we will suggest a new paradigm to classify DM.

In this sense, the Genevan model, represented by Roulet et al. (1985), is a basic starting point. It reconciles the semantic properties of DM with the pragmatic functions that they accomplish. The model distinguishes, on the one hand, textual markers (which refer to relations of meaning in linguistic messages) and, on the other hand, the interactive markers (which depend on the context and on the addressee).

For us, it is necessary to add a third type, enunciative markers that relate to the effort that speakers make when they try to organize their linguistic utterances.

It is also critical to link the concept of modality to the theoretical construct that we present. Above all, we refer to discursive operations of attenuation and intensification that attenuators and intensifiers play in oral speech. It should be noted that not only DM perform these functions, but there are other linguistic expressions that speakers use for these purposes.

Actually, we believe that the modality crosses the semantics of textual DM, such as addition particles (e.g., 'even' may operate as an intensifier), and interactive ones (e.g., 
the Spanish conative $¿ e h ?$, with interrogative intonation, can operate as an attenuator or an intensifier) (Rodríguez-Muñoz 2009b).

It is precisely the theoretical model that we have called pragmatic-perceptive which we take as a reference in our analysis of DM, without discarding some of the ideas that other authors have incorporated to describe the discursive behaviour of these particles often used in conversation.

Therefore, based on the classification of Roulet et al. (1985) for the study of DM, we distinguish two varieties of markers: (a) the textual (or relational) and (b) the interactive types. While the first type has to do with establishing semantic relations between statements, the second highlights the interactive function that certain particles perform in communication exchanges.

Retrieving the proposals of Portolés (1998) and Martín-Zorraquino and Portolés (1999), in this study, we associate interactive markers with conative and focusers of otherness types; that is, this kind of particle points to the listener during the exchange. Besides the three pragmatic dimensions described by Gallardo (2005, 2006, 2007, 2009), we recognize a third type of marker: (c) the enunciative group that we identify with metadiscursives (Portolés 1998; Martín-Zorraquino and Portolés 1999) and we define them as those which represent speakers' effort when they structure and organize the turns in conversation.

Although the phatic nature is implicit in interactive and enunciative subtypes, since they assure contact between speakers and are concerned with the efficient transmission of information, the first points directly to the addressee, while enunciative markers are used as discourse organizers (Galue 2002) and, in that sense, are more associated with the continuous processing of information.

In short, we welcome the tripartite model defined by Gallardo $(2005,2006,2007$, 2009 ) in order to apply it to the pragmatic study of DM. From a perceptive perspective, this classification aims to enhance the point of the communication process in which these particles focus: (1) the addresser, (2) the message, or (3) the addressee. Thus, we will refer to enunciative markers, when particles point to the addresser, to textual markers, when pointing to the message, and to interactive markers, when oriented toward the addressee.

Although a large number of interactive markers are also modality markers, we want to include in a separate category, (4) modals, not just those that are exactly identified as DM, but other words and linguistic expressions that operate as attenuators and intensifiers.

ME indicate the degree of commitment in relation to the truth that speakers express in their utterances. They are communicative strategies that reduce or increase the strength of the assertions and provide further indications about a speaker's attitude in the communication process (Briz 1995, 1997).

Among the words or linguistic expressions that can possess attenuation values in conversation, we distinguish those that indicate (Mendiluce 2005: 231-233):

(a) Approximation: 'nearly' (casi), 'around' (alrededor de), 'more or less' (más o menos), 'approximately' (aproximadamente).

(b) Possibility, probability or doubt: 'maybe' (puede ser), 'possibly' (posiblemente), 'probably' (probablemente), 'perhaps' (quizá/s, tal vez). 
(c) Relativity or limitation in the validity of data: 'I think', 'I believe' (pienso/creo), 'in my opinion' (en mi opinion).

(d) Indeterminacy: 'something' (algo), 'some' (algún), 'certain' (cierto), 'a little', 'a bit' (un poco).

Among intensifiers, we distinguish words and expressions that indicate (Mendiluce 2005: 238-240):

(a) Certainty, conviction and security: 'certainly' (ciertamente), 'surely' (seguramente), 'obviously' (obviamente), 'no doubt' (sin duda).

(b) Necessity and obligation: 'necessarily' (necesariamente), 'must' (deber), 'mandatorily' (obligatoriamente).

(c) Importance: 'main' (principal), 'essential' (esencial).

Furthermore, we cannot forget that modal mechanisms are not restricted to simple words; thus, we admit parts of a sentence ('or something' [o algo], 'or whatever' [o lo que sea]) and even complete sentences ('I don't know' [no sé]). This position is solidly grounded on the idea that all pragmatic phenomena are coded from the repertoire of linguistic resources covering the different linguistic levels defined by tradition. A good example of this is represented by the modality and, within it, by operations of attenuation that include derivational morphology and syntax. From these bases, we develop our own taxonomy which is summarized in Table 1.

\section{Textual markers}

These are based on the semantic relationships between statements and are oriented to the message.

Interactive markers
These perform interactive functions and are
directed to the addressee.

\section{Enunciative markers}

These represent the speaker's effort to structure information.

\section{Modal expressions}

These indicate the speaker's attitude towards his addressee and his own utterances. They manifest the level of commitment that the speaker establishes regarding the truth of his utterances.

\section{Relational/sentence markers}

They indicate addition, option, contrast, consequence, cause, explanation, time, purpose and condition.

\section{Conative/focusers of otherness}

They guarantee the effectiveness of communication exchanges.

Metadiscursive markers

They organize information in speech and serve to maintain the turn of speech.

\section{Attenuators}

Words and phrases that indicate approximation, possibility, probability or doubt, relativity or limitation on the validity of the data and indeterminacy.

\section{Intensifiers}

Words and phrases that indicate certainty, conviction and security, necessity and obligation, and importance. 


\section{Method}

\subsection{Subjects}

40 native speakers of Spanish participated in this study, 20 of them with AS and 20 without developmental disorders. The clinical diagnosis of AS was validated by the psychologists who assisted in data collection. We also used the Social Communication Questionnaire (SCQ) (Rutter, Bailey and Lord 2003) to confirm the presence of an autism spectrum disorder diagnosis. With their parents' written informed consent, participants were videotaped for later analysis.

With respect to the pathological group, 14 subjects with AS were from Asturias (Spain), while the other six came from Valencia (Spain). Data were collected in a person-to-person way in both geographic areas, thanks to the collaboration of the Asturian and Valencian Asperger Associations. The chronologic ages of the patients with AS were between 6 and $15(M=11.15) ; 19$ of them were male and we only counted one recording belonging to a Valencian female. At the moment of data collection, subjects were not under any pharmacological treatment.

The 20 subjects without AS were from Almería (Spain), except for a Mexican female. The control group was composed of 11 males and nine females with chronological ages ranging from 12 to 13 years old $(M=12.35)$. None of them presented psychological or neurological problems, according to the data provided by the Psychopedagogical Orientation Department of IES Argar. The oral data of these participants were also collected in a person-to-person way in the capital of Almería (Spain).

\subsection{Materials}

In order to collect oral data, we designed a graphic support for pragmatic training. The purpose of this instrument was to motivate a semi-oriented and inducted discourse with our participants based on picture description tasks. The support was composed of six illustrated cards with specific contents and independent questions. Thus, the function of the images was the same as a conversational script.

\subsection{Procedure}

The interviews were carried out in different places. The sample of speakers without AS was collected from the Psycho-pedagogical Orientation Department of IES Argar (Almería, Spain), while the pathological sample was taken in diverse multi-use rooms located in the Asperger Asturias and Asperger Valencia Associations. Before the recordings from the designed tasks in the graphic support, we provided the following general instructions to each subject:

I am going to show you six illustrated cards and I will pose you different questions about what you are seeing in each picture. For example, I will ask you to put in the place of 
some characters or to tell me a short story from the drawings. Please try to refer always to the card number.

We then showed participants each illustrated card and posed the questions that were to be answered orally.

\subsection{Corpus}

The corpus that supports the present research is divided into two subcorpora. The first, the differential corpus, was formed by 20 audio recordings coming from non-AS subjects and had a total duration of 97.7 minutes. The second corpus of recordings, which belongs to AS subjects, was also formed by 20 recordings. In this case, materials were in audio-visual format and the duration was 149.3 minutes. Oral data were transcribed in ordinary orthography using the basic notation conventions of conversation analysis (see Appendix).

\subsection{Data analysis}

For location and labelling of the words, we used the textual analysis tool Simple Concordance Program (SCP), version 4.0.9, which allowed us to introduce a quantitative important nuance into our study. This analysis responds to the prevalence of $\mathrm{DM}$ and ME depending on the number of records in the texts. Word List application generated a list of words (or word groups) ordered by frequency from which we worked. In corpus annotation, we used the application Concordance, because we considered dividing the word lists into two types: ambiguous and unambiguous. It is essential to observe the context that precedes and follows them. Unambiguous words, such as $y$ ('and') or pero ('but') were located and labelled automatically from the list of frequencies. However, ambiguous words, those that can take more than one meaning in the texts, as bueno ('well'), that can function in Spanish as a DM or as an adjective, require greater processing cost and detail. Nonetheless, the size of our corpus allowed us, in all cases, to conduct validation of words manually. Finally, we contrast the numerical results generated by the Simple Concordance Program (SCP) with AntConc, version $3.2 .1 \mathrm{w}$, that we applied as a criterion of reliability in our study.

\section{Results}

\subsection{Textual markers}

As Table 2 and Figure 1 reflect, after comparing the results on the use of textual markers in oral speech of TD and AS speakers, we found that, in terms of absolute frequency, there was a slight predominance of these units in the group of subjects with AS. However, the relative frequency $\left(n_{i}\right)$, obtained by dividing the absolute frequency of the 
various types of units used by the total number of words (8.883 in the TD group and 10.397 in the AS group), indicated the opposite $\left(n_{i}=0.1089\right.$ in TD, and $n_{i}=0.0975$ in AS), even though the values were not statistically significant. From a qualitative point of view, we note that the repertoire of textual markers and, consequently, the type of semantic relations that are established in oral speech were more varied in the group of AS speakers.

\begin{tabular}{|c|c|c|}
\hline \multicolumn{3}{|c|}{ Textual markers } \\
\hline \multirow{2}{*}{ Semantic relation } & \multicolumn{2}{|c|}{ Linguistic codification } \\
\hline & TD & $\mathbf{A S}$ \\
\hline Addition & $\begin{array}{l}y \text { ['and'] (401) } \\
e \text { ['and'] (3) }\end{array}$ & $\begin{array}{l}y \text { ['and'] (391) } \\
\text { además ['moreover'] (2) } \\
e \text { ['and'] (1) } \\
\text { hasta ['even'] (1) } \\
\text { incluso ['even'] (1) }\end{array}$ \\
\hline Subtotal & 404 & 396 \\
\hline Option & $o$ ['or'] (67) & $o$ ['or] (51) \\
\hline Subtotal & 67 & 51 \\
\hline Contrast & $\begin{array}{l}\text { pero ['but'] (14) } \\
\text { aunque ['although'] (1) }\end{array}$ & $\begin{array}{l}\text { pero ['but'] (45) } \\
\text { aunque ['although'] (2) } \\
\text { sin embargo ['however'] (1) }\end{array}$ \\
\hline Subtotal & 15 & 48 \\
\hline Consequence & $\begin{array}{l}\text { pues ['thus'] (257) } \\
\text { entonces ['thus'] (28) } \\
\text { así que ['so that'] (1) }\end{array}$ & $\begin{array}{l}\text { pues ['thus'] (157) } \\
\text { entonces ['thus'] (37) } \\
\text { así que ['so that'] (3) }\end{array}$ \\
\hline Subtotal & 286 & 197 \\
\hline Cause & $\begin{array}{l}\text { porque ['because'] (103) } \\
\text { es que ['it's just that'] (6) }\end{array}$ & $\begin{array}{l}\text { porque ['because'] (178) } \\
\text { es que ['it's just that'] (10) } \\
\text { ya que ['since'] (5) }\end{array}$ \\
\hline Subtotal & 109 & 193 \\
\hline Explanation & - & $\begin{array}{l}\text { o sea ['that is'] (4) } \\
\text { vamos ['well'] (3) } \\
\text { es decir ['that is'] (1) }\end{array}$ \\
\hline Subtotal & 0 & 8 \\
\hline Time & $\begin{array}{l}\text { cuando ['when'] (22) } \\
\text { luego ['later'] (19) } \\
\text { después ['afterwards'] (12) } \\
\text { al final ['in the end'] (4) }\end{array}$ & $\begin{array}{l}\text { después ['afterwards'] (34) } \\
\text { cuando ['when'] (19) } \\
\text { luego ['later'] (15) } \\
\text { al final ['in the end'] (3) }\end{array}$ \\
\hline Subtotal & 57 & 71 \\
\hline $\begin{array}{l}\text { Purpose } \\
\text { Subtotal }\end{array}$ & $\begin{array}{l}\text { para ['for', 'in order to'] (14) } \\
14\end{array}$ & $\begin{array}{l}\text { para ['for', 'in order to'] (27) } \\
27\end{array}$ \\
\hline Condition & $s i$ ['if'] (15) & $s i$ ['if'] (23) \\
\hline Subtotal & 15 & 23 \\
\hline TOTAL & 967 & 1014 \\
\hline
\end{tabular}

Table 2: Textual markers used in the oral speech of subjects with TD and AS ordered by absolute frequency 


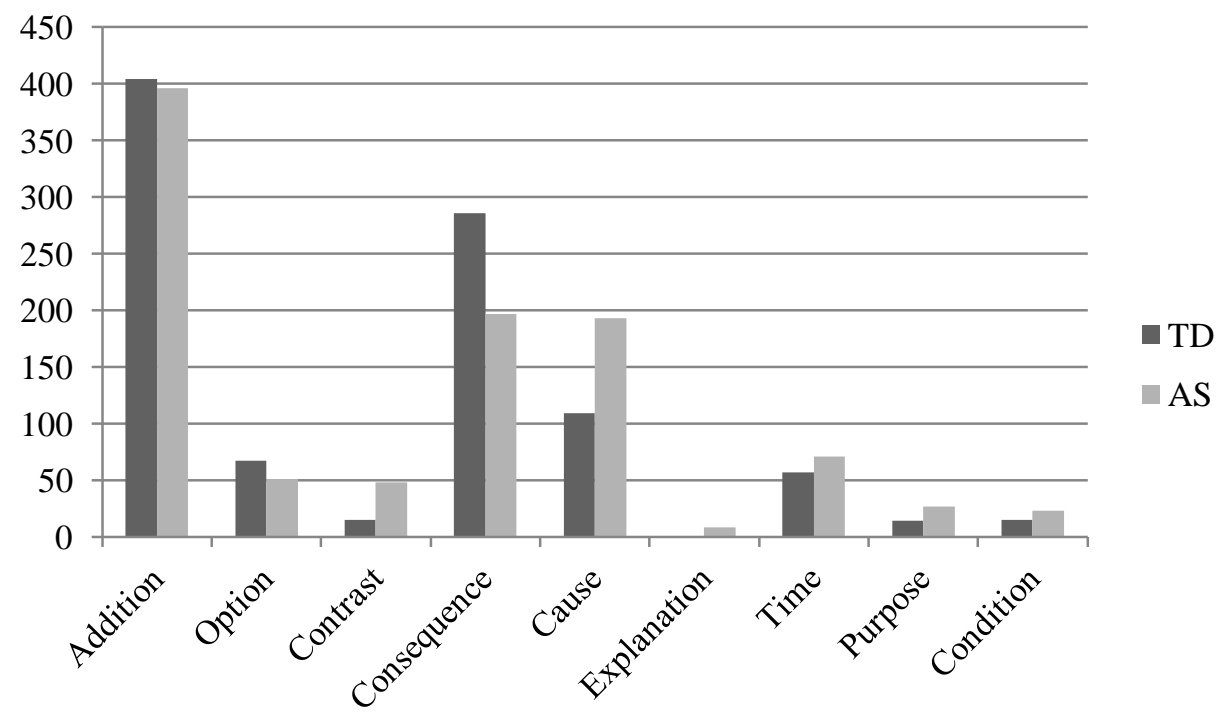

Figure 1: Semantic relations ordered by absolute frequency

\subsubsection{TD speakers}

According to the quantitative data that emerged from our analysis, in the sample of speech from participants without AS, we found that the most frequent semantic relationship established between their utterances was addition (420 records). The conjunction $y$ ('and') (401) was the most productive marker in conversations. Besides coordinating additively with other utterances, its basic discourse function is to mark the continuity of enunciation, suggesting different semantic nuances: contrast, cause, consequence or time (Porroche 2009: 98-99).

The second type of semantic relationship that took on a greater role in our sample was consequence ( 286 records), specially represented by the marker pues ('thus', 'then') (257) that adopts different phonetic variants in conversations: pues (147), puees (7), pueees (2), pos (97), poos (3), pooos (1). As Martín-Zorraquino and Portolés (1999) argue, the most common discursive marker in spoken Spanish is the adverb pues that inserts an informative comment which refers to a preceding discourse segment.

In other words, the marker pues, unlike others such as $y$, apart from establishing the continuation of the enunciation, is used to draw attention to the new information (comment) and, therefore, it adds some data about the content expressed before (topic) (Porroche 2009: 102). In short, as a marker of consequence, it introduces inferences of earlier discourse segments and provides novel information.

Although it is possible to distinguish two basic values for the marker pues, consequence and cause (Miche 1994; Porroche 1996), no examples of use of the latter could be found in our corpus. The consequence value, equivalent to entonces ('then') 
(28), is the most recurrent one in our TD sample. It usually appears in the initial position of utterances and after a pause [1]:

[1] JCS: pues me asustaría, / saldría nadando y cuando se descubriera, / pues ahí yo también me reiría porque es una [broma=]

JCS: then I'd be scared, / I would go swimming and when I realized, / then there I'd also laugh because it's a [joke=]

On the other hand, the absence of other consecutive markers is quite striking, such as por (lo) tanto ('therefore'). The expression of causality (109 records), as with the consequence relationship, finds also a primary correlate in the Spanish conjunction porque ('because') (103). Our TD participants discarded similar connectors such as ya que, puesto que or pues with causal value. Regarding the position of this marker, the general trend is for it to appear inside utterances, as occurs in [2]:

[2] JBC: que este esté enfada(d)o porque han perdido (VIÑETA 1), este, porque están a punto de ganar (VINEETAS 2 Y 3), y este, porque está perdiendo el otro equipo (VIÑETA 4) $\S$

JBC: that this is angry because they have lost (VIGNETTE 1), this, because they are about to win (VIGNETTES 2 AND 3), and this, because the other team is losing (VIGNETTE 4) $\S$

The DM es que ('it's just that') (6), according to Terrádez (2001), is one of the most common in colloquial Spanish and its main task is to introduce an explanation or justification, as in [3] where the speaker has difficulty retrieving a word referring to the facial expression of one of the characters in the vignettes (anomie that, in this case, is not pathological, but seems to be related to lexical poverty):

[3] PLM: en la once, tris- enfado, / en la doce, tristeza, / en la treceee $\rightarrow / /$ eeeh ///(5") es que no sé una palabra quee ponerle pa(ra) [quee-=]

PLM: in the eleven, ang- anger, / in the twelve, sadness, / in thirteeen $\rightarrow$ // uuuh /// (5') it's just that I don't know how to choose a word foor-for this feeling /

The optative relationship (67 records) is exclusively restricted to the use and functionality of the marker $o$ ('or'), a disjunctive conjunction which always introduces an alternative. It is curious that the contrastive semantic relationship is barely represented by 15 contrastive DM in our sample of TD speakers (15 records). The adversative conjunction pero ('but'), common in the inner position of utterances, is the most productive, against the concessive conjunction aunque ('although') that is performed only once in [4]:

[4] CBC: aunque no tiene manchas de nada (SE REFIERE A LA NIÑA DE LAS VIÑETAS QUE NO MUESTRA INDICIOS DE SER LA CULPABLE) (E Y CBC SE RIEN) /

CBC: although they aren't stained (HE REFERS TO A GIRL THAT DOES NOT APPEAR GUILTY) (E AND CBC LAUGH) /

Markers indicating temporality (57 records) do not go beyond the typical in oral speech: cuando ('when') (22), luego ('later') (19), después ('afterwards') (12), al final ('in the end') (4). It is noteworthy that the adverb finalmente ('finally') is never used by our 
participants without AS. The low productivity of temporal markers in the development of the narrative sequences reveals a certain scarcity in the use of these kinds of connectors. Indeed, as organizers, these markers have the common aim of structuring information by drawing on different points of the time axis.

Lastly, the semantic relations of purpose and conditionality are represented by only two markers: para ('for') (14) and si ('if') (15) respectively. For the explanatory semantic relationship, we do not find any representative connector either.

\subsubsection{SA speakers}

According to the data provided from the analysis of textual markers in our sample of AS speakers, the most productive semantic relationship in the oral speech of this group of subjects is the additive one (396 records), with the conjunction $y$ ('and') (391) - plus its contextual variant $e(1)$, before words starting with $i$ - in Spanish - which receives the highest frequency of use. Other particles included in this category are además ('moreover', 'furthermore'), hasta (2) and incluso ('even') (1). The latter two DM show similar discursive behaviour, since they emphasize an element which corresponds, inside the utterance, to an extreme value in a gradient:

[5] AFB: sí, / hasta le pegaría una patada o algo /

AFB: yes, / even I'd kick or something /

[6] AFB: mal, incluso iría a pegarle y le diría hijo de puta, y le pego /

AFB: bad, even I'd go and hit him and say motherfucker, and hit him /

In [5] and [6], we check how the particles hasta and incluso ('even') introduce information that would be at the peak of a gradation, and at the same time the content that these markers present is less expected and more informative.

Quantitatively, the consecutive relationship is the second which has the greatest representation in conversations (198 records). Specifically, pues (157), with a consecutive value (similar to 'then') is the most employed, followed by entonces (37) and asi que (3) ('so that').

The causal relationship (193 records) lies, in numerical terms, very close to the previous one. It is the causal conjunction porque ('because') (178) which has the more increased productivity in our AS sample, followed far behind by es que (it's just that) (10) and ya que ('since') (5). This last conjunctive phrase is a link unit that exhibits similar behaviour to porque [7]:

[7] ACR: mal $\downarrow$, / me sentiría mal $\downarrow$, / ya que es una broma un pocoo- / un poco mala, $\underline{y a}$ que echar sal a un- a un líquido sabría bastante mal $\S$

ACR: bad $\downarrow$, / I'd feel bad $\downarrow$, / since that's a joke a littlee- / a little practical, since mixing salt with a- with a liquid it'd taste quite bad $\S$

At the same time, we get 71 records for textual markers through which AS participants express temporal relationships in their oral speech: después ('afterwards') (34) is the most usual adverb, followed by cuando ('when') (19), luego ('later') (15), and al final ('in the end') (3). 
The disjunctive $o$ ('or') is used on 51 occasions. It is closely followed by contrastive relations (48 records). To the adversative conjunction pero ('but') (45) belong the vast majority of occurrences. Two particles complete this category: aunque ('although') (2) and sin embargo ('however') (1). The last conjunctive phrase introduces a member in the utterance that presents a contrary conclusion which we can infer from the above argument, as shown in [8]:

[8] BFG: eso, hay algunas probabilidades de que-, bueno, de que vaya a ese sitio tod- / todas juntas y s-, jay!, mira, hayy una posibilidad de que primero desde es- desde la señora de- acalorada con- con el hombre de la compra haya una pequeña posibilidad, una diminuta posibilidad (BFG APRIETA EL PULGAR Y EL ÍNDICE DE LA MANO IZQUIERDA) de que vayan al mismo sitio y, sin embargo, sus expresiones son diferentes, lo que quiere decir, no sé, otra cosa I

BFG: that, there are some probabilities that-, well, that they go there a- / altogether and s-, ah!, look, there is a possibility that first from th- from the lady of- the hot lady with- with the man doing the sales there is a small chance, a tiny possibility (BFG SQUEEZES THE THUMB AND FOREFINGER OF THE LEFT HAND) they go to the same place and, however, their expressions are different, which means, I don't know, other thing /

In relation to purpose and conditional relationships, we only find one textual marker for each semantic category: the preposition para ('for') (27) and the conjunction si ('if') (23) respectively.

Explanatory relationships are expressed through the phrases o sea (4) and es decir (1) ('that is'). Both have the same function in communication; indeed, it is the explanatory value, not the consecutive one, which prevails in our conversational examples:

[9] IGL: y en la núme ero cu u atro se está riendo, o sea, contento §

IGL: and in num ber fo ur he is laughing, that is, happy $\S$

[10] DCF: el niño, porque le gastó un timo, le hizo un timo, o sea, lo timó §

DCF: the boy, because he was ripped off, he was ripped off, that is, he was ripped off $\S$

[11] BFG: veamos, eeh el niño eh va a una tienda en la que venden camiones por un euro, / uno cada un euro, claro está, / pero el niño no tiene blanca, / o sea quee vaa- // vaa hacia su abuela, le pide dinerito, un euro, / a ella no le importa un eurito de nada, / y se compra el camión §

BFG: let's see, uuh the boy uh goes to a shop where they sell trucks for one euro, / each one one euro, it's clear, / but the boy has no money, / that is that he goo- / he gooes to his grandma, he asks for a little money, one euro, / she doesn't care about one little euro that's nothing, / and he buys the truck $\S$

In [9] and [10], o sea introduces a clarification about the content that both speakers express in the preceding segment. It is not the case of BFG who exposes through this same phrase a consequence of what was previously expressed in [11].

Finally, vamos (close to 'well') plays, as DM, the corrective function of reformulation and has similar behaviour to the explanatory phrases o sea and es decir in 
Spanish. In the words of Fuentes (2009: 347), this form leads to conclusions, the inferences or implications from the previous comments or information [12]:

[12] MBF: a ver, espera, ¿eh?, // un chico quee- que va a una tienda, vamos, a un kiosco, y ve un camión, bueno, este camión verde era el que quería al final, / ve un camión verde y lo quiere [comprar=]

MBF: alright, wait, eh?, // a boy thaat- that goes into a shop, well, he goes to a kiosk, and he watches a truck, well, this green truck is what he wanted in the end, / and he watches a green truck and he wants to [buy it=]

\subsection{Interactive and enunciative markers}

As shown in Table 3, the differences of use between interactive and enunciative markers are not extreme. However, we notice that these particles are more frequent and varied in our AS sample. Nonetheless, the most significant difference is found in the number of the enunciative markers that they use, clearly higher in the pathological group.

\begin{tabular}{|c|c|c|}
\hline \multicolumn{3}{|c|}{ Interactive markers } \\
\hline \multirow{2}{*}{$\begin{array}{l}\text { Related to } \\
\text { addressee }\end{array}$} & TD & $\mathbf{A S}$ \\
\hline & ¿no? ['isn't that so?'] (13) & $\begin{array}{l}\text { ¿no? ['isn't that so?'] (14) } \\
\text { hombre ['man'] (8) } \\
\text { oye ['hear'] (2) } \\
\text { ¿eh? ['eh?'] (1) }\end{array}$ \\
\hline TOTAL & 13 & 25 \\
\hline \multicolumn{3}{|c|}{ Enunciative markers } \\
\hline \multirow{2}{*}{$\begin{array}{l}\text { Related to } \\
\text { addresser }\end{array}$} & TD & $\mathbf{A S}$ \\
\hline & $\begin{array}{l}m m \text { ['hum'] (60) } \\
\text { eh ['uh'] (11) } \\
\text { bueno ['well'] (6) }\end{array}$ & $\begin{array}{l}\text { bueno ['well'] (81) } \\
m m \text { ['mm'] (54) } \\
\text { eh ['uh'] (50) }\end{array}$ \\
\hline TOTAL & 77 & 185 \\
\hline
\end{tabular}

Table 3: Interactive and enunciative markers used in the oral speech of subjects with TD and AS ordered by absolute frequency

\subsubsection{TD speakers}

Interactive markers, with conative function, which appeal directly to the addressee in conversation - in all our cases, the interviewer - and fulfil the task of maintaining contact with this, are not too abundant in our sample of TD speakers and are specified in a single marker: ¿no? ('isn’t that so?’) (13 records).

As Rodríguez-Muñoz (2009b) has pointed out, ¿no? and ¿eh? ('eh?') share a functional equivalence in oral speech. There is only one example where ¿eh? constitutes an independent question with the meaning of ¿cómo? ('how?'). We cannot accept this variant as a DM [13]: 
[13] TCC: (INATENTA) $\mathbf{i e h ? ~ / ~ e n ~ l a ~ c i n c o , ~ q u e - ~ q u e ~ e l ~ n i n ̃ o ~ q u i e r e ~ i r ~ a ~ c o m p r a r ~} \uparrow$ / juguetes y // cómics y to(do) eso $\S$

TCC: (INATTENTIVE) eh? / in five, that- that the boy wants to go shopping $\uparrow$ / games and // comics and so on $\S$

Therefore, the marker $i n o$ ? is the only one that manifests conative behaviour in our interactions, always maintaining its shape and interrogative intonation in the final position of utterances. Under this first value, this particle allows the semantic commutation with other markers such as ¿(me) entiendes?, ¿(me) comprendes?, ('do you understand (me)?’) ¿me sigues? (‘do you follow me?’), ¿sabes?, (‘do you know?'), ¿vale? ('okay?') or ¿sí? ('yes?'), as shown in [14] and [15]:

[14] AGR: pues esa (VIÑETA 10) estáá- tiene calor, ¿no? ((y)) aquí (VIÑETA 11) este está enfada(d)o, / este está triste (VIÑETA 12), / este está un poco desorienta(d)o (VIÑETA 13), / este está feliz porque está escuchando música (VIÑETA 14) y este también (VINETA 15) $\S$

AGR: so that (VIGNETTE 10) iis- is hot, isn't that so? ((and)) here (VIGNETTE 11) this is angry, / this is sad (vignette 12), / this is a bit disoriented (vignette 13), / this is happy because she is listening to music (VIGNETTE 14) and this one too (VIGNETTE 15) $\S$

[15] PBH: pues un niño que va a una juguetería, ¿no?, a un puesto de juguetes, / y no tiene dinero, / entonces va corriendo y le pide dinero a su abuela, / y se compra un coche $\S$

PBH: so a boy that's going to a toy shop, isn't that so?, to a place of toys, / and he has no money, / thus he goes running and asks for some money from his grandma, / and he buys a car $\S$

However, the confirmatory value of ¿no? is the most prevalent one in the conversations with TD speakers. In such cases, the marker ¿no? usually has a communicative function of factual verification. That is, the speakers attempt to verify the validity of the propositional content expressed in their utterances, and it is possible to substitute ¿no? with other Spanish expressions like ¿no es cierto? or ¿no es verdad? ('is it true?'), as in [16] and [17]:

[16] JJCC: pos que el niño- $\rightarrow$, que le está- está echando- esto es sal, ¿no? que le [está echando sal-=]

JJCC: well that the boy- $\rightarrow$, that he's- he's throwing- that's salt, isn't it?, that he [is throwing salt-=]

[17] NFC: pues que está viendo la televisión, ino? $\oint$

NFC: well that he's watching television, isn't he? $\S$

The enunciative markers that TD speakers handle regarding the reformulation of their responses' information are $e h$ ('uh') (11), with neutral or declarative intonation, and $\mathrm{mm}$ (60), with its pronunciation variants $\mathrm{mmm}$ (6) and umm (1). In both cases, speakers use these particles in order to fill or occupy the silence along their oral intervention. At the same time, its use produces a delay in the emission while the speaker is organizing their 
mental information. This fact explains the variability of position in utterances, as in [18] and [19]:

[18] CBC: queee- ¿qué es esto, gas?, ;ah, sal! (INTENTA LEER LAS LETRAS DEL DIBUJO EN

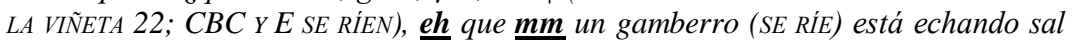
en el azúcar $\S$

CBC: thaaat- what's that, gas?, ah, salt! $\uparrow$ (HE TRIES TO READ THE DRAWING'S LETTERS IN VIGNETTE 22; CBC AND E LAUGH), uh that $\underline{\mathbf{m m}}$ a hooligan (HE LAUGHS) is throwing salt into the sugar $\S$

[19] SFA: $\underline{\mathbf{m m m}} /$ no lo- / puede $\S$

SFA: $\underline{\mathbf{m m m}} / \mathrm{I}$ don't- / maybe $\S$

Of the eight records that we obtain in our conversations, except for two occasions when bueno ('well') is used to express a clear agreement by the participants, it is always used as a metadiscursive marker. In such situations, we identify the value of this marker with self-repair and self-correction in discourse through which the speaker adds a clarification concerning a former member of the utterance. In [20] DDG self-corrects when he realizes that he is explaining the vignette number five instead of the first one:

[20] DDG: $\underline{\text { eeh }}$ en la uno $\rightarrow$ que- $\rightarrow, \underline{\text { bueno }}$, en la cinco, quee el niño quiere comprar un juguete, I en la seis, que no tiene dinero, / en la siete, que va corriendo a su casa, I en la ocho que le pide-le pide dinero a su abuela, / y en la nueve se va a comprar un juguete $\$$

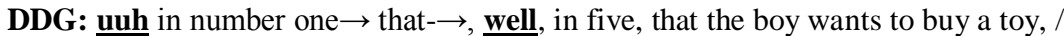
in six, that he has no money, / in seven, that he goes running to his house, / in eight that he asks- he asks for some money from his grandmother, / and in nine he goes to buy a toy $\S$

\subsubsection{SA speakers}

Among the interactive markers, those that are listener-oriented, the most prevalent in our AS sample is ¿no? ('isn't that so?') (14) and, with a similar pragmatic functionality, we find ¿eh? ('eh?') (1). Oye ('hear') represents a DM which comes from a verb of perception grammaticalized in the second person singular. Thus, it is used by the speaker to draw the addressee's attention and it has been called peripheral connector (Pons 1998). For Fuentes (2009: 244), this particle behaves like a DM with an interactive contact value because it points directly at the interlocutor. As we see in [21], it is frequent that the speaker uses it in order to introduce a new topic in conversation:

[21] E: =Álvaro, uy, ya hemos acabado, ¿eh?, muchas gracias $\S$

E: =Álvaro, uy, we've already finished, eh?, thank you very much $\S$

APC: oye, ¿po- puedo hacer unas cosas? (QUIERE HACERLE GESTOS A LA CAMARA) §

APC: $\underline{\text { hear, }}$ ¿ca- can I do any things? (HE WANTS TO DO GESTURES TO THE CAMERA) $\S$

Despite its multipurpose nature, we believe that hombre ('man') (8) [22] has a core value of appeal (as vocative) and, in this sense, it is a highly interactive marker (Gaviño 2011): 
[22] E: vale, ¿y tú te sentirías de la misma forma si te gastaran una broma así? § E: ok, and would you feel in the same way if they played a joke like that on you? $\S$ DMF: bue-, hombre, yo me fijaría por el color del agua, yo me fijaría §

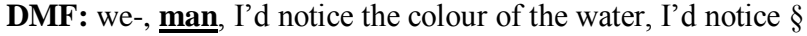

The most numerous examples of enunciative markers correspond to bueno (81), mm (54) and $e h$ ('uh') (50), the same particles that TD speakers express in their communicative oral exchanges. As shown in Figure 2, both groups of speakers produced a higher quantity of enunciative markers in comparison with interactive ones.

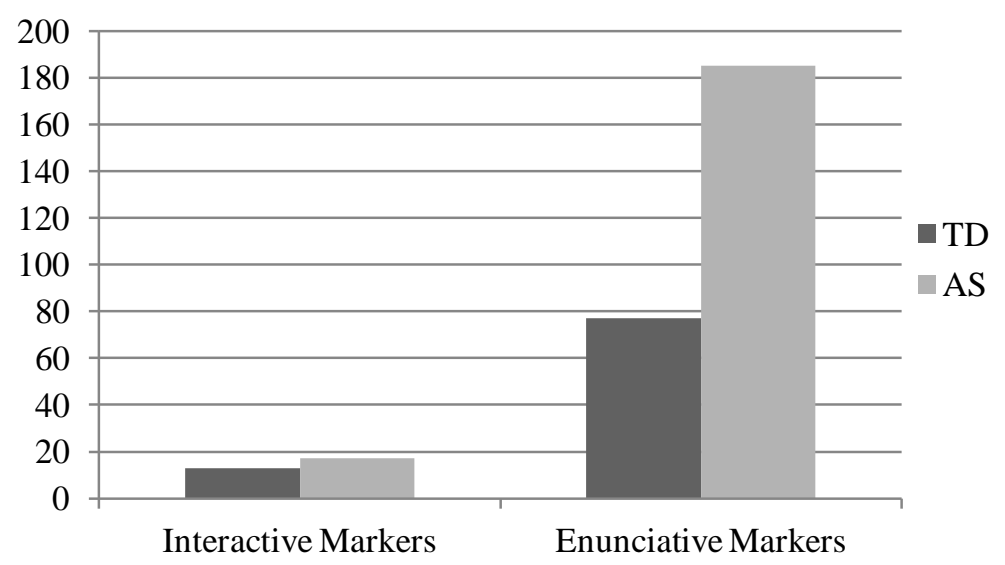

Figure 2: Predominance of enunciative markers in the oral speech of subjects with TD and AS

\subsection{Modal expressions: attenuators and intensifiers}

In the analysis of ME, restricted to attenuation and intensification mechanisms, we realize that attenuators are used more often by both groups of speakers. Nevertheless, as Table 4 reflects, there is a non-representative increase of intensification's elements in the oral speech of AS speakers if we compare these results with those of the TD group. 


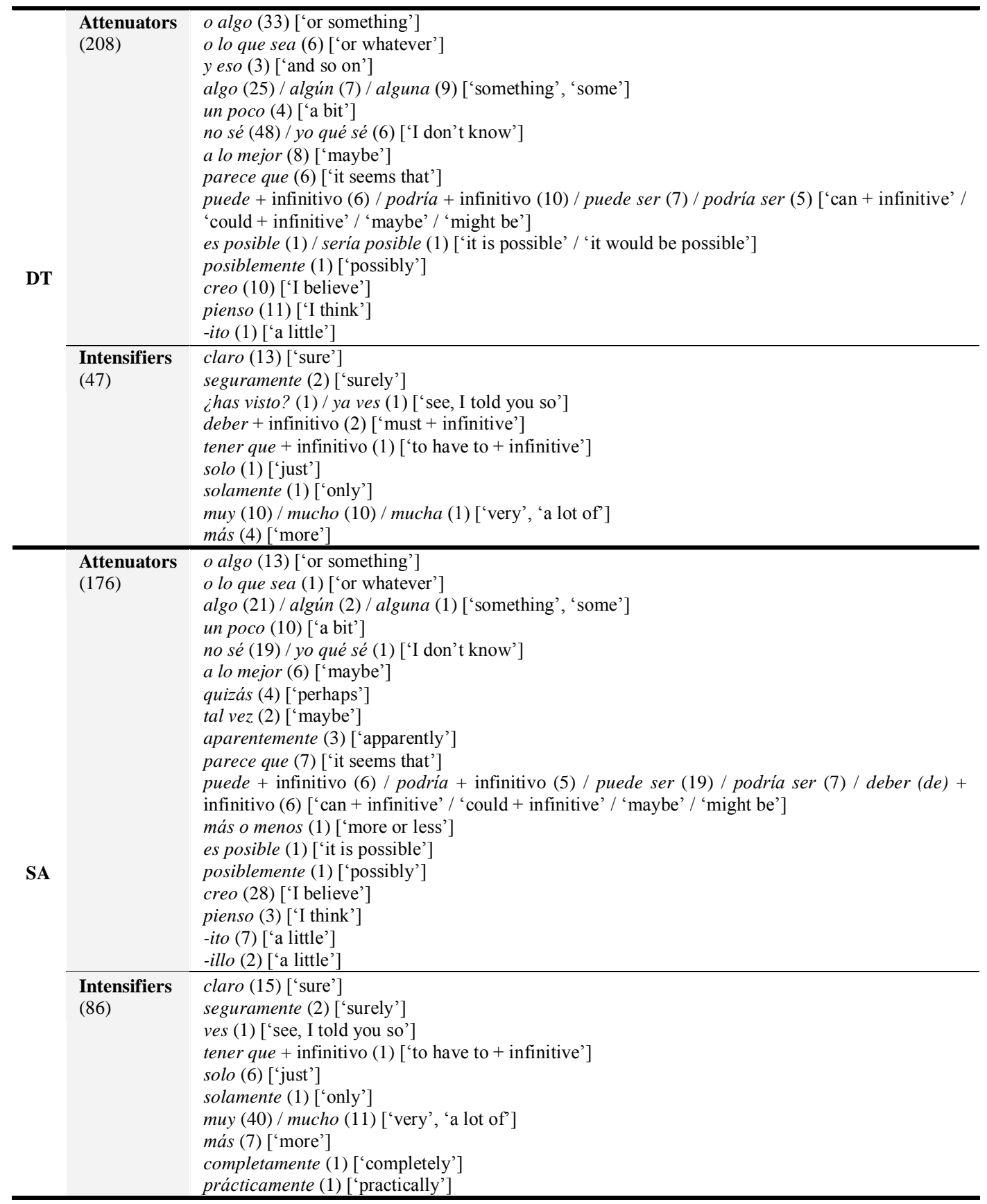

Table 4: ME in the oral speech of subjects with TD and AS ordered by absolute frequency 


\subsubsection{TD speakers}

Following Porroche (2009: 223), the ME's domain constitutes a complex process which decisively involves the speaker's expressiveness. This takes into account several linguistic resources associated with phonic, syntactic, lexical and/or semantic levels. Thus, all these procedures affect different grammatical categories (substantives, verbs, adverbs, interjections, etc.).

Among discursive attenuators, the most frequent ones are those that express indetermination or doubt. The most repeated form that TD participants use for indetermination is o algo ['or something'] (33), equivalent to o lo que sea ['or whatever'] (6). Both modal Spanish locutions permit certain mobility inside the utterances, although they usually appear in terminal positions. Their functions are similar to suspension points in written modality and, from this point of view, they substitute a part of the utterance which is intentionally or unintentionally omitted. A third locution that behaves in this way is y eso ['and so on'] (3), another type of discursive closure organizer (Fuentes 2009: 358).

Without being preceded by $o$ conjunction, the indefinite pronoun algo ['something'] (25) is also frequently seen with a clear attenuation function in examples [23], [24] and [25], as well as the modifiers algún (7) and alguna (9) ['some'] or the expression un poco ['a bit'] (4).

[23] PBH: tch pues aqui (VINETA 1), pues mm un programa de lucha libre o algo $\oint$ PBH: tch well here (VIGNETTE 1), well mm a wrestling programme or something $\S$

[24] AHM: pues // debería decirl- decirle o algo que se tranquilice, yo qué sé $\oint$ AHM: well // he should te- tell him or something so he calms down, I don't know $\S$

[25] EGH: een la primera, que está viendo algo y se ha enfada(d)o $\S$

EGH: iin the first, he's watching something and he's angry §

E: uhum $\S$

E: uhum $\S$

EGH: en la segunda, que está intriga(d)o viendo algo, / y en la terc- en la tercera, que está viendo una novela o algo y está llorando (SE RIE) §

EGH: in the second, he's intrigued watching something, / and in the th- in the third, he's watching a soap opera or something and he's crying (HE LAUGHS) $\S$

No sé (48) and yo qué sé (6) ['I don't know'] indicate uncertainty or doubt in assertions. Despite finding cases in Spanish where no sé constitutes a whole utterance, the tendency exhibited in our conversations is completely the opposite, that is, it usually relates to a former segment inside the utterance that this locution closes. Its semantic value is near to other DM such as tal vez or quizás ['perhaps'], but we do not find any example of them in our conversations.

The closure formulations $o$ algo ['or something'] and yo qué sé ['I don't know'] serve to complete the utterances in an imprecise way. For Vigara (1980: 78), these forms are used like conceptual fillers that avoid specifying the utterances' sense and they just insinuate it from previous content. In [26] we realize how MMM expresses doubt and indetermination simultaneously in her response. 
[26] MMM: pos / en la diez $\rightarrow$, no sé, esfuerzo o algo de eso $\S$

MMM: well / in ten $\rightarrow$, I don't know, effort or something like that $\S$

The adverbial locution a lo mejor ['maybe'] (8) is also used to indicate uncertainty and doubt in utterances (see Bañón 1999 for details). The same function corresponds to the verbal construction parece que ['it seems that'] (6). Moreover, the participants tend to use different forms of poder ('to can') and its Spanish periphrastic derivatives for the expression of possibility or conjecture according to its modal values, that is, puede + infinitive ['can + infinitive'] (6), podría + infinitive ['could + infinitive'] (10), puede ser ['maybe'] (7), podría ser ['might be'] (5) and equivalent locutions such as es posible ['it is possible'] (1) and sería posible ['it would be possible'] (1), or even the adverb posiblemente ['possibly'] (1).

On the contrary, the use of mentalist verbs for expressing relativity about the content that utterances present is not so frequent: creo ['I believe'] (10) and pienso ['I think'] (11). On another note, we just find one example of attenuation through appreciative suffixation, cochecito ['little car'] (1).

With an intensification value, claro ['sure'] (13) is the predominant particle as a certainty and conviction mark in our TD sample. This epistemic modal expression is always linked to a former utterance and it shows agreement in relation to that content [27]. Furthermore, it permits mobility inside the utterances, but it usually appears in initial or terminal positions. This particle's sense is comparable to other adverbs' meaning, for instance, exactamente ['exactly'], ciertamente ['certainly'] or obviamente ['obviously'], and some verbal locutions such as por supuesto ['of course'], examples that are absent in our corpus.

[27] E: ¿tú habrías reaccionado igual? §

E: would you have had the same reaction? §

AGR: claro, jvaya susto! $\S$

AGR: sure, what a fright! §

Seguramente ['surely'] (2) is another modal operator that speakers may use like a reinforcement of the assertions' propositional content. Nonetheless, it could also express the opposite value, that is, uncertainty, but we only register those examples whose meaning is near to sin duda ['no doubt'] or indudablemente ['undoubtedly'] where it behaves like an epistemic intensifier. We find two evidence marks, ihas visto? (1) and ya ves (1) ['see, I told you so'], that share a similar purpose [28]:

[28] NFC: ¿has vist(o)?, yy-y al final, que se come la sal en vez del azúcar, y la niña se parte de [risa]

NFC: see, I told you so!, aand- and at least, he eats salt instead of sugar, and the girl cracks [up]

The periphrastic forms associated with obligatory modality are practically inexistent in the oral speech of TD subjects: deber + infinitive ['must + infinitive'] (2) and tener que + infinitive ['to have to + infinitive'] (1). Similarly, we just find two adverbs which indicate exclusion: solo ['just'] (1) y solamente ['only']. It is not the case of some quantifiers that are used to upgrade the content of the assertions: muy ['very'] (10), mисho (10), mисha (1) ['a lot of'] and más ['more'] (4). 


\subsubsection{AS speakers}

The tendency that AS speakers manifest is, in general, the same as the TD group's, that is, the number of ME that are used like attenuation strategies double those which are used to intensify the utterances' propositional content.

Among the attenuation units, y eso ['and so on'] disappears and three new elements are included in the oral speech of AS speakers: quizás ['perhaps'] (4), aparentemente ['apparently'] (3) and tal vez ['perhaps'] (2). All of them serve to express uncertainty and doubt by relativizing the conviction about the explicit information as shown in [29], [30] and [31]:

[29] VGC: eem está asustado $\downarrow$,// porque quizás ((uno)) está a punto de marcar gol §

VGC: eem he's scared $\downarrow$,// because perhaps $(($ one $))$ is about to score a goal $\S$

E: vale, ¿el tercero? /

E: ok, and the third one?

VGC: está llorando, / porque quizás / su equipo favorito / ha perdido el par- ha perdido el partido $\S$

VGC: he's crying, / because perhaps / his favourite team / has lost the gam- has lost the game $\S$

[30] ACR: ha hecho una tarta $\uparrow, y y / y$ parece quee aparente- aparentemente su hijo $\uparrow$ / huele la $t$ - el olor de la tarta I/

ACR: she has baked a cake $\uparrow$, and / and it seems thaat apparent- apparently her son $\uparrow /$ is smelling the c- the cake's smell //

[31] ACR: en la once tal vez dicee- / tal vez el señor fuera empresario yy y su- y su empresa puede estar cayendo muy bajo $\S$

ACR: in the eleven perhaps it saays- / perhaps the gentleman was a businessman aand and his company was getting worse and worse $\S$

As an attenuation mechanism, we find nine appreciative suffixation examples in our AS sample. The words ended by -ito are: perrito ['little dog'] (2), camioncito ['little track'] (1), cochecito ['little car'] (1), dinerito ['little money'] (1), eurito ['little euro'] (1) and poquito ['little bit'] (1). The suffix -illo is less productive and it is just represented by the word graciosillo ['little joker'] (2).

Secondly, and in comparison with the results that we commented on for the control group, we appreciate a slight predominance of linguistic units that reinforce or intensify the propositional content of the utterances in our AS sample. However, the repertoire of words is similar in both cases. We must indicate the inclusion of the upgraders in the sample of speech coming from the group of speakers with pathology: completamente ['completely'] (1) and prácticamente ['practically'] (1).

\section{Discussion}

First of all, we cannot maintain that there are statistically significant differences in relation to the textual markers used by TD and AS speakers in conversation. Although the results of absolute frequency indicate a slight predominance in the use of these 
particles in favour of the pathological population, if we consider the data of relative frequency in both groups, the quotients are placed very close. In terms of relative frequency, our calculations suggest that the recurrence of this type of units is superior in the oral speech of the group without pathology $\left(n_{i}=0.1089\right.$ against $n_{i}=0.0975$, in SA).

In addition, data of absolute frequency reveal that TD subjects surpass slightly the other group's results in the production of textual markers that express additive and optative relationships and, more markedly, the consecutive ones. On the contrary, textual connectors are more numerous in the oral speech of AS subjects when they express semantic relations of contrast, cause, explanation and, not so markedly, temporal, final and conditional textual relationships.

Nevertheless, we appreciate that this set of textual markers is broader and more varied in the conversations of patients diagnosed with AS. More precisely, we find new particles to express textual relations: addition - además ['in addition'], hasta e incluso ['even'] -, contrast - sin embargo ['however'] - and cause - ya que ['since'] -. The explanatory relations are absent in the sample of TD speakers, but AS subjects express them through the locutions $o$ sea and es decir ['that is'] and through the reformulation marker vamos ['well'].

As for the preference of certain semantic relations on others, we verify that the additive relationship is the most frequent in both groups, followed by the consecutive one. Nonetheless, the number of particles that TD speakers use at the time of expressing these textual relations is higher in their oral speech. That is what also occurs with the disjunctive conjunction $o$ ['or']. However, the causative, contrastive, temporal, final, conditional and explanatory relations are more productive, in terms of absolute frequency, in the conversations of AS speakers.

We cannot either maintain that there are exponential statistical differences with respect to the use of interactive markers $\left(n_{i}=0.0015\right.$ in the TD group and $n_{i}=0.0024$ in the AS group), although the repertoire is also more varied in the case of individuals diagnosed with AS where we find two units with conative function (focusers of otherness) as they are hombre ['man'] and oye ['hear']. This type of DM is the one that has minor relevance and representativeness in our conversational corpus.

The differences are much clearer in the use of enunciative markers between TD and AS speakers. Even though being similar to the particles' repertoire in both groups, the quotient of relative frequency is superior in AS speech $\left(n_{i}=0.0178\right)$, compared with the results of the control group $\left(n_{i}=0.0087\right)$.

TD speakers display slightly more attenuated speech than AS individuals. In particular, $n_{i}=0.0234$ in the control group, whereas $n_{i}=0.0169$ in the group of AS subjects. In contrast, the participants diagnosed with AS are those that produce a greater number of intensifiers during communicative exchange, because $n_{i}=0.0083$ in the case of these last ones, against the value $n_{i}=0.0053$ in speakers without developmental problems. Although these quantitative differences are not sufficiently relevant, it is precise to insist that the number of mechanisms of attenuation is significantly superior to the one of the intensifiers in the oral speech of both groups.

Really, we must confirm our initial hypothesis about the small differences that we anticipated finding in the use of DM and ME between TD and AS speakers. From a qualitative view point, AS subjects use a more varied group of DM, and, from a quantitative one, enunciative markers predominate in the oral speech of such speakers. 


\section{Conclusions}

In this research we have contributed to a new approach to the study of MD and ME. Mainly, we have proposed a pragmatic-perceptive model for its analysis. Consequently, we conceived three groups of markers according to the perceptive enhancement that they carry out: enunciative, textual and interactive markers are respectively focused on the addresser, on the message and on the addressee. In particular, we have compared the use and functionality of these three types of markers in a sample of 20 TD and 20 SA speakers.

Our findings are symptomatic of: (a) a high expertise in the use of cohesive mechanisms in the oral speech of subjects with AS, as it testifies to the accomplishment of a more varied repertoire of units of that type; and (b) a greater necessity to use enunciative markers that allow one to reconstruct the information that speakers try to transmit to their addressees. Further research could demonstrate the appropriate command that AS individuals exhibit at the time of using textual markers, oriented to the discursive cohesion property, and the abuse of enunciative markers in conversation that represents the efforts that AS speakers make when they construct their utterances.

\section{Acknowledgments}

This paper stems from the $\mathrm{PhD}$ dissertation entitled Pragmatic deficits in the oral speech of children with Asperger syndrome, directed by Drs. Bañon-Hernández and FornielesAlcaraz, with International Mention and supported by FPU Research Grant AP200801707 funded by the Ministry of Education, Culture and Sport (Government of Spain). The research is part of the project "Ampliación y adaptación del corpus PERLA de datos clínicos en el marco del proyecto internacional Childes/Talkbank: perfiles pragmáticos y propuestas de intervención" (FFI2012-39325-C03-01) funded by the Ministry of Economy and Competitiveness (Government of Spain). It has been possible thanks to the admirable cooperation of the Asperger syndrome associations of Asturias and Valencia. I also express my gratitude to the participants in this study and their families.

\section{References}

Bañón, A. 1999. Apuntes para el análisis sintáctico-semántico de la locución a lo mejor en español hablado. In J. A. Samper and M. Troya (eds.), Actas del XI Congreso Internacional de la Asociación de Lingüistica y Filología de la América Latina, Volume 1. Las Palmas de Gran Canaria: Nogal Ediciones: 137-146.

Bañón, A. 2003. El estudio discursivo del contraste. A propósito de las estructuras adversativas. In J. L. Girón, J. Herrero, S. Iglesias and A. Narbona (eds.), Estudios ofrecidos al profesor José Jesús de Bustos Tovar. Madrid: Universidad Complutense de Madrid: 937-951.

Briz, A. 1995. La atenuación en la conversación coloquial. Una categoría pragmática. In

L. Cortés (ed.), El español actual. Actas del I Simposio sobre Análisis del Discurso Oral. Almería: Universidad de Almería: 101-122. 
Briz, A. 1997. Los intensificadores en la conversación coloquial. In A. Briz, J. R. Gómez-Molina, M. J. Martínez-Alcalde and Val.Es.Co. (eds.), Pragmática y gramática del español hablado. El español coloquial. Zaragoza: Pórtico: 13-36.

Briz, A., S. Pons and J. Portolés. 2008. Diccionario de partículas discursivas del español. Available at <http://www.dpde.es/>.

Cortés, L. 1991. Sobre conectores, expletivos y muletillas en el español hablado. Málaga: Ágora.

Cortés, L. and M. M. Camacho. 2005. Unidades de segmentación y marcadores del discurso: elementos esenciales en el procesamiento discursivo oral. Madrid: Arco/Libros.

Fraser, B. 1990. An approach to discourse markers. Journal of Pragmatics 14(3): 383-395.

Fuentes, C. 1987. Enlaces extraoracionales. Sevilla: Alfar.

Fuentes, C. 1995. La sintaxis de los relacionantes supraoracionales. Madrid: Arco/Libros.

Fuentes, C. 1996. Ejercicios de sintaxis supraoracional. Madrid: Arco/Libros.

Fuentes, C. 2007. Sintaxis del enunciado: los complementos periféricos. Madrid: Arco/Libros.

Fuentes, C. 2009. Diccionario de conectores y operadores del español. Madrid: Arco/Libros.

Gallardo, B. 2005. Categorías inferenciales en pragmática clínica. Revista de neurología 41(Suppl. 1): S65-S71.

Gallardo, B. 2006. Más allá de las palabras y su estructura: las categorías del componente pragmático. In E. Garayzábal (ed.), Lingüistica clínica y logopedia. Madrid: Antonio Machado Libros: 81-196.

Gallardo, B. 2007. Pragmática para logopedas. Cádiz: Universidad de Cádiz.

Gallardo, B. 2009. Valoración del componente pragmático a partir de datos orales. Revista de neurología 48(Suppl. 2): S57-S61.

Gallardo, B. and M. J. Marín. 2005. Marcadores discursivos procedentes de verbos perceptivos en el discurso afásico. Revista de Investigación Lingüistica VIII: 53-94.

Galué, D. 2002. Marcadores conversacionales: un análisis pragmático. Boletín de Lingüistica 18: 27-48.

Gaviño, V. 2011. Operaciones metalingüísticas del marcador discursivo hombre. MarcoELE. Revista de didáctica ELE 12: 1-11.

Halliday, M. and R. Hasan. 1976. Cohesion in English. London: Longman.

Loureda, Ó. and E. Acín. 2010. Los estudios sobre marcadores del discurso en español, hoy. Madrid: Arco/Libros.

Mancera, A. and M. E. Placencia. 2011. Los marcadores del discurso en la construcción de habla de contacto en un contexto de servicio en el español peninsular. Revista Internacional de Lingüistica Iberoamericana IX, 2(18): 145-171.

Martín-Zorraquino, M. A. 1998. Los marcadores del discurso desde el punto de vista gramatical. In M. A. Martín-Zorraquino and E. Montolío (eds.), Los marcadores del discurso. Teoría y análisis. Madrid: Arco/Libros: 19-53.

Martín-Zorraquino, M. A. and J. Portolés. 1999. Los marcadores del discurso. In I. Bosque and V. Demonte (eds.), Gramática descriptiva de la lengua española, Volume 3. Madrid: Espasa Calpe: 4051-4213. 
Mendiluce, G. 2005. Estudio comparado inglés/español del discurso biomédico escrito: la secuenciación informativa, la matización asertiva y la conexión argumentativa en la introducción y la discusión de artículos biomédicos escritos por autores nativos y no-nativos. Valladolid: Universidad de Valladolid.

Miche, E. 1994. Description sémantico-pragmatique de la marque espagnole pues. Cahiers de linguistique française 15: 51-76.

Pons, S. 1998. Oye y mira o los límites de la conexión. In M. A. Martín-Zorraquino and E. Montolío (eds.), Los marcadores del discurso. Teoría y análisis. Madrid: Arco/Libros: 213-218

Porroche, M. 1996. Las llamadas conjunciones como elementos de conexión en el español conversacional: pues/pero. In T. Kotschi, W. Oesterreicher and K. Zimmermann (eds.), El español hablado y la cultura oral en España e Hispanoamérica. Frankfurt/Madrid: Vervuert/Iberoamericana: 71-94.

Porroche, M. 2009. Aspectos de gramática del español coloquial para profesores de español como L2. Madrid: Arco/Libros.

Portolés, J. 1998. Marcadores del discurso. Barcelona: Ariel.

Rodríguez-Muñoz, F. J. 2009a. Síndrome de Asperger. Materiales y aproximación pragmalingüística. Valencia: Universidad de Valencia.

Rodríguez-Muñoz, F. J. 2009b. Estudio sobre las funciones pragmadiscursivas de ¿no? y ¿eh? en el español hablado. Revista de lingüística teórica y aplicada 47(1): 83-101.

Rodríguez-Muñoz, F. J. 2013. Evaluación pragmática de niños con síndrome de Asperger. Munich: Lincom Verlag.

Roulet, E., A. Auchlin, J. Moeschler, C. Rubattel and M. Schelling. 1985. L'articulation $d u$ discours en français contemporain. Bern: Peter Lang.

Rutter, M., A. Bailey and C. Lord. 2003. The Social Communication Questionnaire. Los Angeles, CA: Western Psychological Services.

Schiffrin, D. 1987. Discourse markers. Cambridge: Cambridge University Press.

Terrádez, M. 2001. Frecuencias léxicas del español coloquial: análisis cuantitativo y cualitativo. Valencia: Universidad de Valencia.

Vigara, A. M. 1980. Aspectos del español hablado. Madrid: SGEL.

\section{About the author}

Francisco J. Rodríguez Muñoz received his $\mathrm{PhD}$ in Linguistics from the University of Almería, where he currently teaches undergraduate and graduate courses in Applied Linguistics and Spanish. His research interest and publications focus on Clinical Linguistics and Pragmatics. 




